\title{
Retention of Employees at a Private Sector Small Bank, Chennai
}

\author{
K. Padmavathi, S. Geethalakshmi, G. Sundharavadivel
}

\begin{abstract}
Employee retention is not something that can be dealt with records and reports. It depends purely upon how the employers understand the various concerns of the employees and how they help them resolve their problem, when they are in need. Therefore the main aim of this study is to study the employee retention at a private sector small bank in Chennai. To achieve the said objectives of the study data was collected from around 100 employees from the total population of 450 employees using convenience sampling technique. The research design used in this study is descriptive research design. Primary data was collected using a structured questionnaire and secondary data was obtained from company website, journals and books. The Independent variable used for the study are Age, gender, marital status, educational qualification, experience and monthly income and the dependent Variables are Compensation \& Rewards, Work Environment, Organization Culture \& Relationship, Job Satisfaction \& Security, Training \& development and Social relevance of working life. Percentage analysis were used to break the raw data. From the study it is found that majority of the respondents are above the age group of 20 years, majority are male and are UG. It is further found that employee retention helps in the development of the organization and management comes forward to solve the employees problem. Employees feel valued and appreciated, be given feedback, provided with growth opportunities, be given work-life balance options, have trust and confidence in their leaders.
\end{abstract}

Keywords : Employee Retention, Compensation \& Rewards, Work Environment, Organization Culture \& Relationship, Job Satisfaction \& Security, Training \& development and Social relevance of working life.

\section{INTRODUCTION}

$\mathrm{E}_{\text {mployee Retention is defined as an organization's }}$ ability to retain its employees. It can also be called as a process, in which the resources are motivated and encouraged to stay in an organization for a longer period of time for the sustainability of the organization. The ultimate aim of Employee Retention is to make both the stakeholders, i.e., employees and employer happier. It facilitates loyal employees sticking to the company for a longer duration, which in turn will benefit both the stakeholders.

Revised Manuscript Received on December 05, 2019.

* Correspondence Author

K. Padmavathi *, Research Scholar, Department of Adult \& Continuing Education, School of Social Sciences, University of Madras, Chennai, India.

S. Geethalakshmi, Research Scholar, Department of Adult \& Continuing Education, School of Social Sciences, University of Madras, Chennai, India.

Dr. G. Sundharavadivel, Professor, Department of Adult \& Continuing Education, School of Social Sciences, University of Madras, Chennai, India

\section{NEED FOR THE STUDY}

The current study paves way to know, the reasons why the employees prefer to change their job and the factors which make employee dissatisfied with their job. The originations requires such kind of studies in order to assess the overall interest and the feelings of the employees towards their nature of job and organization. It is also helpful to the management to concentrate and work on its core weaknesses by the suggestions and recommendations prescribed in the project.

\section{SCOPE OF THE STUDY}

The study has scope in the following areas

- It provides suggestion for decreasing the attrition level in the organization.

- It helps the management to find the weaker parts which the employee's feels towards the organization and also results in converting the identified weaker part in to stronger by providing the optimum suggestions or solutions.

\section{REVIEW OF LITERATURE}

According to Balamurugan \& Abinaya (2016) Employee Retention is the key challenges faced by IT Organization. Employees being the assets of any organization and organization will not be ready to lose its employees easily. The present paper is to identify the major causes for employee turnover and analyze the factors involved in retaining employees and find the most prominent employee retention strategies adopted by the organization. It is concluded that employee turnover increases the attrition rate and reduces the retention of employees. Employee retention reduces the product cost, productivity is increased and takes care of brain drain of the particular industry.

Ednah \& Geoffrey (2017) said that many organizations fail to consider the factors which determine employee retention as a strategy in managing competition and are likely to become victims of industry competition. The purpose of the study was to find out the factors affecting employee retention in an organization in University of Eldoret. Specific objectives were to determine effects of compensation on employee retention. 
The study findings indicated that compensation, had significant relationship with employee retention. It is recommended that university should enhance a higher rate of employee retention and they should also ensure availability of comprehensive range of training, skill and career. This not only paves way for satisfaction among employees but also results in growth

\section{RESEARCH DESIGN}

The type of research used for the purpose of the study is Descriptive in nature. It is further decided the sampling unit as private sector small bank Chennai, in that convenience sampling technique is selected. Total number of sample participants is 100 from 450 employees. Survey method is employed to collect the data from the respondents and the data are collected using close ended self-administered questionnaire. Secondary data was collected from many websites, books, journals and other research studies which have already been collected by someone else and which have already been passed through the statistical process. The raw data collected through questionnaires is converted into quantitative data with the help of percentage analysis. From the quantitative data inferences and interpretation are drawn.

\section{OBJECTIVES OF THE STUDY}

- To study the employee retention among employees at a Private Sector Small Bank, Chennai

- To know whether the employee retention helps in development of the organization.

- To ascertain the role of management in coping the problems of the employee.

- To suggest various measure of work life balance.

\section{LIMITATIONS OF THE STUDY}

- The employees may not have revealed the exact information because of various external factors.

- The study is restricted to only one branch in Chennai city and it cannot be taken to be representation of entire small bank industry.

- Sample size was confined to limited respondents as many of the employees were available to collect the data. The study is conducted considering the prevailing conditions which are subject to change in future.

\section{ANALYSIS OF DATA}

The below table clearly depicts the demographic variables involved in the study

Table - 1: Distribution of Demographic Variables

\begin{tabular}{|l|c|c|}
\hline \multicolumn{1}{|c|}{ Demographic Profile $(\mathbf{N}=\mathbf{1 0 0})$} & Frequency & Percentage \\
\hline Age & & \\
\hline Below 20yrs & 20 & $30 \%$ \\
\hline $21-30$ & 30 & $30 \%$ \\
\hline $31-40$ & 28 & $28 \%$ \\
\hline $41-50$ & 22 & $22 \%$ \\
\hline Gender & & \\
\hline
\end{tabular}

\begin{tabular}{|l|c|c|}
\hline Demographic Profile $(\mathbf{N}=\mathbf{1 0 0})$ & Frequency & Percentage \\
\hline Male & 66 & $66 \%$ \\
\hline Female & 34 & $34 \%$ \\
\hline Marital Status & & \\
\hline Married & 63 & $63 \%$ \\
\hline Unmarried & 37 & $37 \%$ \\
\hline Educational Qualification & & \\
\hline UG & 46 & $46 \%$ \\
\hline PG & 54 & $54 \%$ \\
\hline Others & 0 & $0 \%$ \\
\hline Total Experience & & \\
\hline Less Than 5Yrs & 45 & $45 \%$ \\
\hline 5-10yrs & 30 & $30 \%$ \\
\hline 10-15yrs & 15 & $15 \%$ \\
\hline Above 15yrs & 10 & $10 \%$ \\
\hline
\end{tabular}

Table - 2: Distribution of Dependent Variables

\begin{tabular}{|l|c|c|}
\hline \multicolumn{1}{|c|}{ Dependent Variables (N = 100) } & Frequency & Percentage \\
\hline Employee Retention Helps in Development & & \\
\hline Strong Agree & 45 & $45 \%$ \\
\hline Agree & 25 & $25 \%$ \\
\hline Neutral & 20 & $20 \%$ \\
\hline Disagree & 5 & $5 \%$ \\
\hline Strong Disagree & 5 & $5 \%$ \\
\hline Work Life Balance is Supported & & \\
\hline Strongly Agree & 26 & $26 \%$ \\
\hline Agree & 36 & $36 \%$ \\
\hline Neutral & 23 & $23 \%$ \\
\hline Disagree & 10 & $10 \%$ \\
\hline Strongly Disagree & 5 & $5 \%$ \\
\hline Management Clears Employees Problems & & \\
\hline Strongly Agree & 36 & $36 \%$ \\
\hline Agree & 24 & $24 \%$ \\
\hline Neutral & 20 & $20 \%$ \\
\hline Disagree & 15 & $15 \%$ \\
\hline Strongly Disagree & 5 & $5 \%$ \\
\hline
\end{tabular}

\section{FINDINGS OF THE STUDY}

- The study found that majority of the respondents (30\%) are around the age group of below 20 years.

- Majority of the respondents are male (66\%).

- Further it is found that majority of the respondents are married $(63 \%)$.

- It is observed that majority of the respondents are ug $(54 \%)$.

- It is observed that majority of the respondents are less than $5 y r s(45 \%)$ of experience

- The respondents said that Employee retention do help in the development of the organization.

- Majority of the respondents are of the view that work life balance is supported in the organization.

- Further the study shows that management comes forward to solve the employees problems

Published By: 


\section{SUGGESTIONS FOR THE STUDY}

Employees often find they can enjoy a 10 to 20 percent salary increase by simply moving from one company to the next, which makes jumping ship attractive. Pay them right. Keep a tab on industry compensation standards. Structure the bonus and benefits well

Businesses expect their professionals to be fully trained and well certified enough to carry on the given work in a proper manner. Yet too many aren't willing to invest in helping them maintain the said credentials. Therefore either employees should be sent to a learning center or should be provided with membership in one of the e-learning sites available. Which makes them to see it as an investment in their career.

\section{CONCLUSION}

One of the main aim of majority of the organization is to earn profit. But in order to attain the maximum profit, the organization should concentrate more on employees and the ways to retain them in the long run. One of the biggest impacts on a company's productivity is employees satisfaction. In case high performing employees leave the company it is even more difficult to attract new talent if those employees have left the company because of dissatisfaction. This survey provides valuable input which are directly given by employees, it provides a clear understanding on how the employees perceive the organization. Job provides an opportunity for the employees to exercise their skills at work place. It is observed that there is a scope for the improvement in working conditions for which certain suggestions are discussed. Further it is identified that lack of growth opportunities and salary are the major factors which force employees to change their jobs. So the company should take steps to initiate proper growth opportunities in respect of career as well as skill enhancement which insists the employees indirectly to stay in the organization for a longer period of time. Thus it's clear that having proper retention strategies is key in order to retain employees

\section{REFERENCES}

1. Balamurugan \& Abinaya(2016), “A Study On Employee Retention Strategies In Leading It Companies At Trichy”, Intercontinental Journal Of Human Resource Research Review, 4(3), 42-49, ISSN: 2320-9704 Online ISSN:2347-1662.

2. Ednah \& Geoffrey (2017), "Factors Affecting Employee Retention At The University Of Eldoret, Kenya", IOSR Journal of Business and Management (IOSR-JBM), 19(3), 109-115, e-ISSN: 2278-487X, p-ISSN: 2319-7668.

\section{AUTHORS PROFILE}

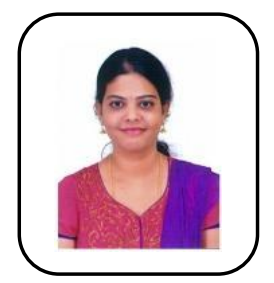

The name of First Author is "K.Padmavathi". She has completed B.Com, MBA (HRM) and M.Phil(HRM). She has done a Certificate Course in Business \& HR Analytics from Loyola Institute of Business Administration (LIBA). Currently the author is pursuing Full Time Ph.D. in Management at Department of Adult \& Continuing Education, University of Madras. On April 2017 the author hascleared Tamilnadu State Eligibility Test for Assistant Professor (TNSET) in Management subject.The author has worked as guest lecturer at Department of Adult \& Continuing Education, University of Madras. She has published research papers in reputed International Journals. She is also a life member in All India Council for Mass Education and Development. She was also a faculty coordinator for National level seminar on "Challenges for Human Resource Management in the Changing Environment" organized by the Department of Adult \& Continuing Education, University of Madras. The Author also has hands on research experience during MBA and M.Phil (HRM).

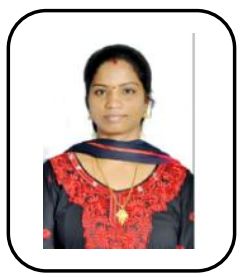

The name of Second Author is "S. Geethalakshmi". She has completed BBA, MBA and M.Phil. (HRM). Currently the author is pursuing Full Time Ph.D. in Management at Department of Adult \& Continuing Education, University of Madras. The author has worked as Assistant Professor at Nazarath Arts \& Science College, Avadi and Shree Chandraprabu Jain College, Minjur. The author has been recognized for producing above $87 \%$ result in Practical Auditing and EDP subject in Chandraprabhu Jain College. The author has also worked as Processor in GNSA InfoTech Pvt Ltd for 4 years and as Advisor in Barclays Shared Services for 4.5 Years. During her professional experience the author has received "Super Star" award and "The Ambassador" award from Barclays Shared Services. She has also participated in workshops to enhance her teaching skills.The Author also has hands on research experience during MBA and M.Phil. (HRM).

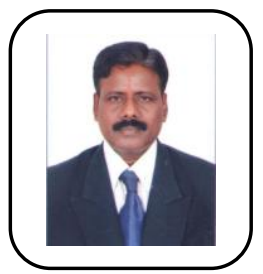

The name of Third Author is "Dr.G. Sundharavadivel". $\mathrm{He}$ is a "Professor" at Department of Adult \& Continuing Education, University of Madras with more than 15 years of Experience in the field of Adult and Continuing Education.The author is a rank holder in MA (Andragogy), did Ph.D. in Vocational Education from the University of Madras. He did his M.L.M, MBA and M.Phil.(Entrepreneurship) from M.K. University. The author completed M.S.W, M.Sc. (Yoga) from Annamalai University and PGDHRM from Pondicherry University. The author served as programme officer NSS from 2005 to 2010 and has presented papers in National and International seminar, Conferences and workshops.The author has also completed M.COM (Education Management).The author has received "AasiriyarSemmal" award from Thamizhaga Institute of Educational Research and Advancement (TIERA) on teacher's day, September 5th 2019 and "Best professor" award from ESN Publications on 28th September 2019.He has published in the reputed and UGC approved journals. 